\title{
Identification of new deep sea sinuous channels in the eastern Arabian Sea
}

\author{
Ravi Mishra ${ }^{*}$, D. K. Pandey², Prerna Ramesh ${ }^{2}$ and Peter D. Clift ${ }^{3}$
}

\begin{abstract}
Deep sea channel systems are recognized in most submarine fans worldwide as well as in the geological record. The Indus Fan is the second largest modern submarine fan, having a well-developed active canyon and deep sea channel system. Previous studies from the upper Indus Fan have reported several active channel systems. In the present study, deep sea channel systems were identified within the middle Indus Fan using high resolution multibeam bathymetric data. Prominent morphological features within the survey block include the Raman Seamount and Laxmi Ridge. The origin of the newly discovered channels in the middle fan has been inferred using medium resolution satellite bathymetry data. Interpretation of new data shows that the highly sinuous deep sea channel systems also extend to the east of Laxmi Ridge, as well as to the west of Laxmi Ridge, as previously reported. A decrease in sinuosity southward can be attributed to the morphological constraints imposed by the elevated features. These findings have significance in determining the pathways for active sediment transport systems, as well as their source characterization. The geometry suggests a series of punctuated avulsion events leading to the present array of disconnected channels. Such channels have affected the Laxmi Basin since the Pliocene and are responsible for reworking older fan sediments, resulting in loss of the original erosional signature supplied from the river mouth. This implies that distal fan sediments have experienced significant signal shredding and may not represent the erosion and weathering conditions within the onshore basin at the time of sedimentation.
\end{abstract}

Keywords: Submarine canyon, Deep sea channel system, Indus Fan, Arabian Sea

\section{Background}

Deep sea channel systems are recognized as important components of continental margin bathymetry, due to their pivotal role in shaping the morphology of submarine fans. Submarine fans are the largest clastic accumulations on Earth and receive sediment through canyon-channel systems. The sediment transfer zones between terrestrial sources and deep sea depositional sinks include submarine canyon-channel systems, which generally transition from erosional $\mathrm{V}$-shaped canyons indenting the upper and mid slope of the continental shelf, to U-shaped channels with over bank deposits across the lower continental slope and rise (Covault 2011). Despite this role in connecting the continent and the deep sea it is not always

\footnotetext{
*Correspondence: ravimishra@ncaor.gov.in; drravimishra@gmail.com ${ }^{1}$ IODP-India, National Centre for Antarctic and Ocean Research, Headland Sada, Vasco-Da-Gama, Goa 403804, India
}

Full list of author information is available at the end of the article clear how canyons transform from being incisive on the continental slope to being constructive on the abyssal seafloor. If sediment is stored and reworked from locations along a channel system then this may be a source of signal shredding between the source and ultimate sink, in addition to the shredding seen in alluvial flood plains (Castelltort and Van Den Driessche 2003; Jerolmack and Paola 2010). Quantifying the buffering role that channel systems play and how this evolves downslope is best achieved by better mapping of active channels on the largest submarine fans. This is crucial if the abyssal turbidite record is to be used to understand evolving continental environmental conditions in the source regions.

Although the basic model in which avulsing depositional lobes migrate across the surface of a submarine fan has been well-established, it is often unclear what controls the architecture of a channel belt in detail and thus the distribution of the subsequent sedimentary deposits. Examples within the geological record are documented 
but typically lack the spatial extent to be able to fully understand how the basin geometry controls channel morphology. In foreland basins the longitudinal aspect of the basin usually acts to guide the geometry of the channels (De Ruig and Hubbard 2006) but in more open systems such as deep-sea basins the role of ridges or seamounts is less well-defined.

Since the advent of marine data acquisition techniques in the late twentieth century, high-resolution bathymetry, marine seismic and deep-tow sonar equipments have made it possible to investigate deep water canyonchannel systems (Normark 1970; Damuth et al. 1983). Canyon-channel systems in various submarine fans have been studied in detail by many researchers e.g. Gorsline (1970), Prins et al. (2000), Curray et al. (2003), Bourget et al. (2010), Normark (1970, 1978), Covault et al. (2012), Deptuck et al. (2003), Wynn et al. (2007), and Mishra et al. (2015). The cross sections and transverse profiles of various deep sea channel systems have been studied to understand the channel morphology, geometry, slope and even the channel migration (Griggs and Kulm 1970; Mahar and Zaigham 2013; Bourget et al. 2010; Curray et al. 2003; Kamesh Raju et al. 1993; Subrahmanyam et al. 2008; Babonneau et al. 2002). Though there have been numerous studies of submarine canyons and deep-sea channel systems worldwide, very little has been reported from the Indian Ocean due to lack of data, although some profiles across the Indus Canyon were presented by Kolla and Coumes (1991), McHargue and Webb (1986) and Clift et al. (2014).

The Indus Canyon system, situated in the Arabian Sea (Deptuck et al. 2003; Clift et al. 2014), is the second largest canyon system worldwide after the Bay of Bengal (Bouma et al. 1985). The morphological features of the eastern Arabian Sea have been previously studied using single beam, satellite altimetry and conventional Hydrosweep multibeam systems (Basu et al. 1994; Das et al. 2007; Hillier and Watts 2007; Rao et al. 1992; Bhattacharya and Subrahmanyam 1991; Bhattacharya et al. 1994; Iyer et al. 2012). There are several channels that have been reported by previous workers in the middle and lower Indus Fan and channel systems have been reconstructed (Kenyon et al. 1995; Mackenzie 1997; Prins et al. 2000; Mishra et al. 2015; Prerna et al. 2015). Active channels in the middle Indus Fan have been identified from multibeam bathymetry at $20^{\circ} \mathrm{N}$ (Fournier et al. 2011; Rodriguez et al. 2011). Geological Long Range Inclined Asdic (GLORIA) side scan sonar (Kenyon et al. 1995; Prins et al. 2000) was used to map channels in the middle Indus Fan, west of the Laxmi Ridge. Sinuous channels have also been mapped by multibeam bathymetry in the lower Indus Fan at $12^{\circ}-13^{\circ} \mathrm{N}$ latitude and $67^{\circ}-68^{\circ} 30^{\prime} \mathrm{E}$ longitude (Kodagali and Jauhari 1999).

The channels identified in the present study (Fig. 1) are part of middle Indus Fan and their connectivity has been established with the main Indus Canyon-channel system (Prerna et al. 2015), using satellite gravity derived bathymetry data (Smith and Sandwell 1997). This paper presents more detailed study of Indus Fan system based on the interpretation of new bathymetry data. We have described the morphology and structure of the active channel systems and also identified new channels proximal to the eastern flanks of the Laxmi Ridge in the Arabian Sea (Fig. 2). The Indus channel system has been reconstructed based on the new identified channels (Fig. 1b).

\section{Regional setting}

The Arabian Sea, located in north-western Indian Ocean, contains the Indus Fan which is the dominant sedimentary feature in the region (Fig. 1). The Indus Fan is located at the junction between the Arabian, Eurasian and Indian Plates and is juxtaposed against the Western Continental Margin of India (WCMI), which is passive continental margin (Fig. 1a). At the north-western periphery of the fan, the Eurasian plate over thrusts the Arabian plate forming the Makran Accretionary Prism (McCall 1997). The transform boundary between the Arabian and Indian plates extends from the Owen Ridge (Owen Fracture Zone, Fig. 1), north to the Murray Ridge and onshore to the Chaman Fault (Fournier et al. 2008). The Carlsberg Ridge is located along the southwest periphery of the fan, whereas in the east it is bounded by the marginal highs associated with the WCMI (Fig. 1a).

The WCMI evolved after Gondwana break-up (about $90 \mathrm{Ma}$ ) and is about 40 m.y. younger than the Eastern Continental Margin of India (ECMI) (Subrahmanyam and Chand 2006). Subsequent rifting and seafloor spreading during the middle Cretaceous (India-Madagascar break-up) as well as India-Seychelles break-up during late Cretaceous (MacKenzie and Sclater 1971; Naini and Talwani 1982; Minshull et al. 2008) gave rise to the WCMI. Sediment accumulation began to speed up along this passive margin following the late Oligocene to early Miocene (Clift et al. 2001), India-Eurasia collision and initial Himalayan uplift during the early Eocene (Najman et al. 2010; Sahni and Kumar 1974; Dewey and Bird 1970). The post-rift Himalayan fan sedimentation is believed to have been underlain by the earlier pre and syn-rift deposits derived from peninsular India in this region (Clift et al. 2002; Pandey and Pandey 2016). 


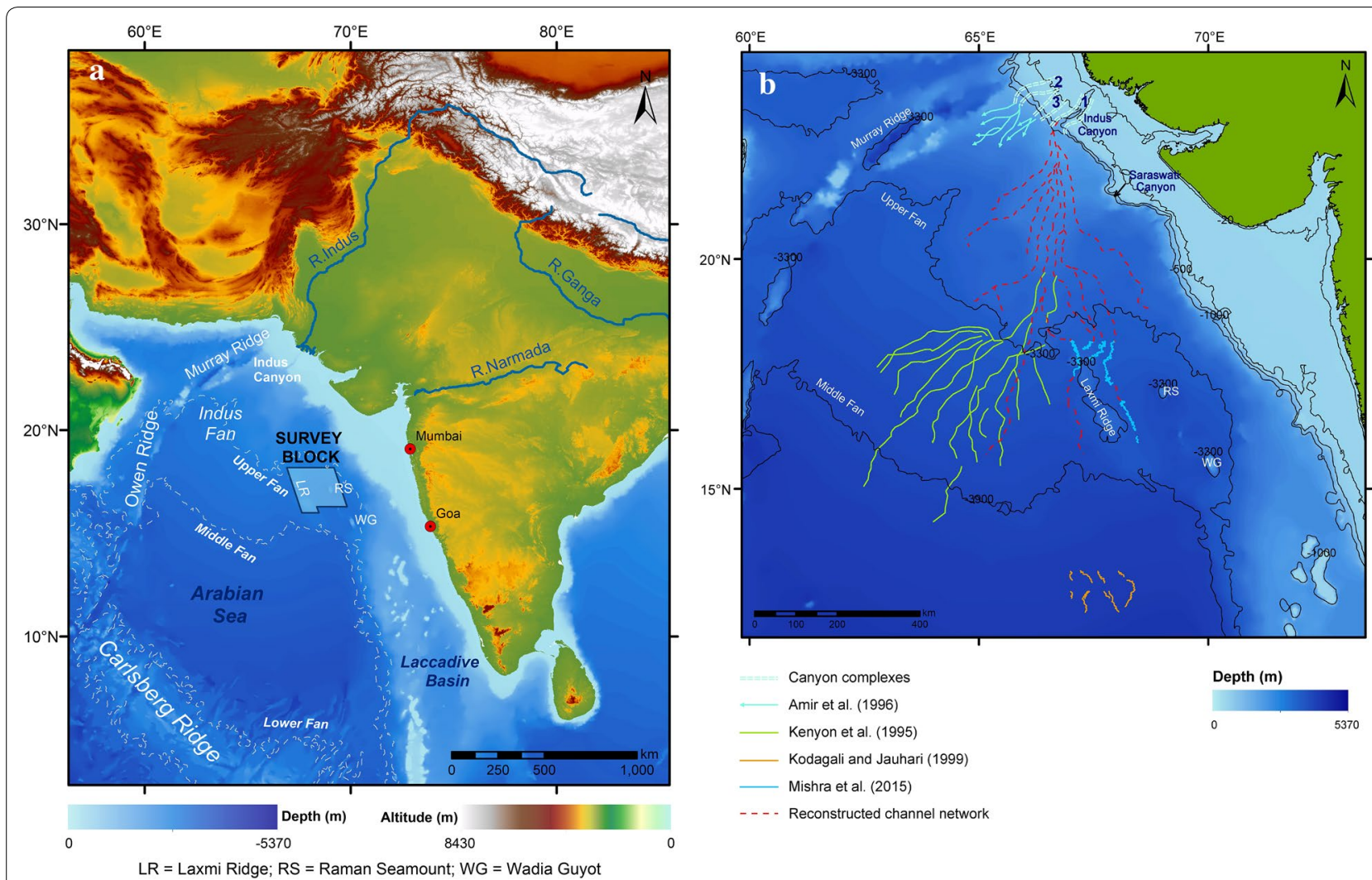

Fig. 1 a Land-to-deepsea sediment routing system of River Indus flowing from Himalayan region and depositing sediments to the Arabian Sea forming the Indus Fan is depicted here. Indian subcontinent; upper, middle and lower Indus Fan margins; and major fluvial rivers such as Indus, Ganga and Narmada are also shown in the map. Survey block, in which channels discussed in this study, is marked for reference. b Reconstruction of Indus channel system from global bathymetry data is marked. Channels identified in upper and middle fan from Kenyon et al. (1995) and Prins et al. (2000); channels from lower fan identified by Kodagali and Jauhari (1999) are marked. Channels identified by Mishra et al. (2015) which are explained in greater detail in this study are also shown. A reconstruction of the channel network from the Indus Canyon to the identified channels using global bathymetric data (Smith and Sandwell 1997) is portrayed for creating a generic pattern of channel network in the upper Indus Fan (Prerna et al. 2015)

\section{Terrestrial to marine sediment routing system of River Indus \\ River Indus and delta}

The Indus River is one of the major rivers of Asia, which originates on the Tibetan Plateau and flows south-westerly through alluvial plains traversing around $3200 \mathrm{~km}$ before reaching its delta (Fig. 1a) at the Arabian Sea (Mirza 2005; Inam et al. 2007). The terrestrial Indus basin covers approximately 1.12 million $\mathrm{km}^{2}$ (Hartmann and Andresky 2013). The Indus River drains barren, unconsolidated glacial and fluvial reworked detritus eroded from high-relief, rapidly uplifting tectonic units of the western Tibetan Plateau, Karakoram and Himalaya (Milliman et al. 1984; Clift 2002); this supplied to the fifth largest river sediment load in the world prior to damming in the last century (Wells and Coleman 1984).

Sediments are either deposited in the delta, which covers $8000 \mathrm{~km}^{2}$ (Clift and Giosan 2014), or bypass through the Indus Canyon from where they may subsequently be deposited into the deep sea abyssal plain (Kolla and Coumes 1984; Prins et al. 2000).

\section{Indus Canyon and channel system}

Canyon-channel systems provide routes to transport and deposit sediment into the deep-sea and are primarily observed along continental margins. Deepwater canyonchannel systems have been identified in various geographic contexts, but their seaward extent is limited to a few hundred kilometers from the shelf and only some canyons extend beyond $1000 \mathrm{~km}$ (Covault et al. 2012).

The two largest canyon-channel systems of the world are in the Indian Ocean, namely the Ganga-Brahmaputra system in Bay of Bengal and the Indus system of Arabian Sea. The prominent Indus Canyon and its associated deep-sea channel system can be observed from multibeam bathymetry and satellite derived global bathymetry data (Von Rad and Tahir 1997; Ryan et al. 2009; Clift et al. 2014). The Indus Canyon, classified as a delta front 

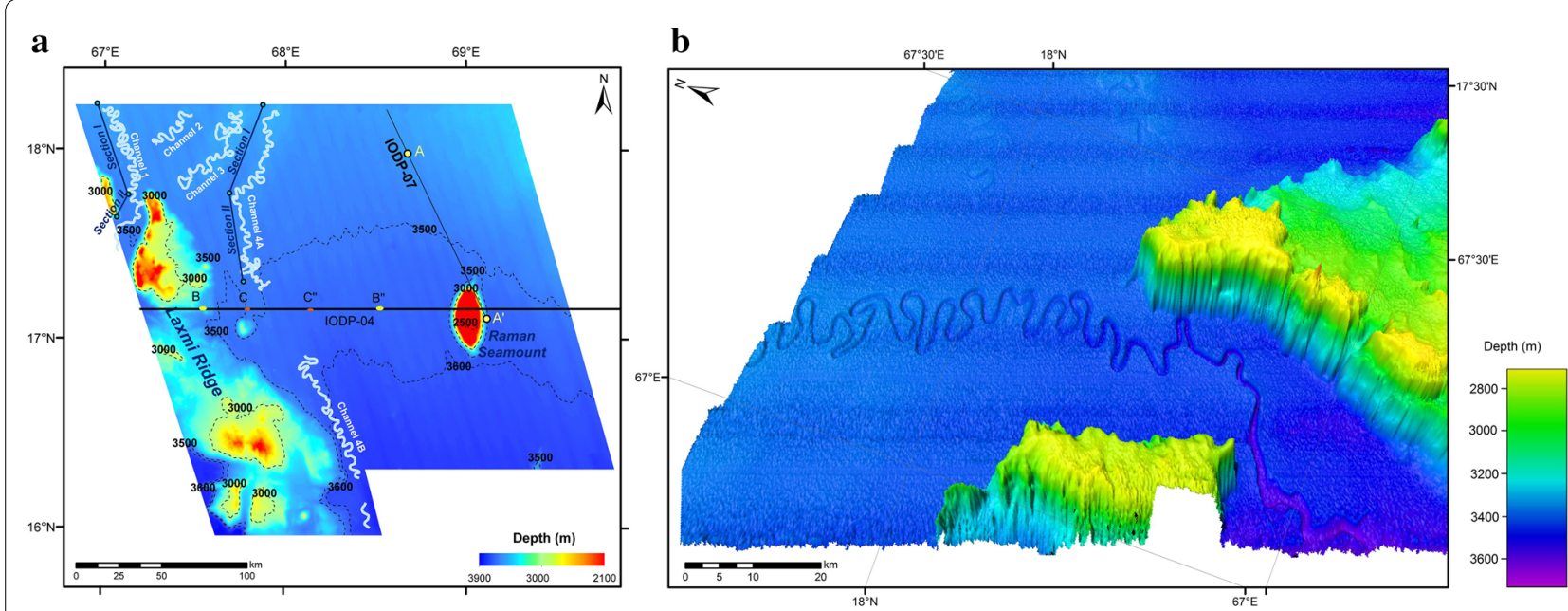

Fig. 2 a Bathymetry map of the study area as derived from swath bathymetric data acquired using Multibeam SB 3012 system. The ensonified features-Laxmi Ridge, Raman Seamount and submarine channels (1, 2, 3, 4A, 4B) have been marked. Contours represent depth ranging $2100-3900 \mathrm{~m}$ BMSL (Below Mean Sea Level) at an interval of 100 m; Seismic tracks IODP-04 and IODP-07 used in this study are also marked. Segments AA', BB' and $C^{\prime}$ are elaborated in Figs. 3C, 4 and 5 respectively. $\mathbf{b} 3$ D visualization of Channel 1 flowing in between the northern reaches of Laxmi Ridge is provided here. Vantage point is WSW-ENE. Vertical exaggeration is increased to $5 \times$ in order to highlight the south-ward deepening trend followed by Channel 1. Channel 2 and 3 can also be lightly identified towards NE of Channel 1

trough (Shepard and Dill 1966), creates an indent on the $\sim 100 \mathrm{~km}$ wide continental shelf. The canyon extends across the continental slope with an average width of $8 \mathrm{~km}$ and a maximum depth of $1200 \mathrm{~m}$ at the shelf edge. At $1400 \mathrm{~m}$ water depth, the canyon widens to $20 \mathrm{~km}$ and is $325 \mathrm{~m}$ deep (Wynn et al. 2007 and references therein). In that area the canyon transitions into the depositional channel levee systems on the upper fan. Erosional channels extending on to the middle fan are smaller, with depth ranging 30-40 m and relatively small levees, while the lower fan is characterized by numerous small channels $(<1.5 \mathrm{~km}$ wide and $<5 \mathrm{~m}$ deep) with or without small levees (Wynn et al. 2007).

Only one canyon-channel system has been active on the Indus margin at any one time (Bourget et al. 2013; McHargue and Webb 1986; Kolla and Coumes 1987; Kenyon et al. 1995; Von Rad and Tahir 1997; Prins et al. 2000; Wynn et al. 2007). The modern active Indus channellevee system has been mapped by GLORIA long range side scan sonar (Kenyon et al. 1995; Prins et al. 2000) and the distal part of this system was further imaged with a multibeam swath bathymetry system (Kodagali and Jauhari 1999; Mishra et al. 2015). At present, the active Indus Canyon (185 km long and up to $1.6 \mathrm{~km}$ deep) is the main feeder canyon (Fig. 1b) of the Indus submarine fan (Kenyon et al. 1995; Von Rad and Tahir 1997; Prins et al. 2000; Bourget et al. 2013; Clift et al. 2014).

Three palaeo-canyon systems have been recognized in the shelf and upper slope area of the Indus Fan (Fig. 1b), two of which lie to the west of the modern active Indus
Canyon, while a third (the Saraswati Canyon) is to the southeast (McHargue and Webb 1986; Kolla and Coumes 1987; Droz and Bellaiche 1991; Clift et al. 2002; Deptuck et al. 2003; Bourget et al. 2013). In the presently active Indus Canyon system, temporal changes over the last $~ 100$ years have included westward canyon shifting (Mahar and Zaigham 2013).

\section{Indus Fan}

As turbidity currents reach abyssal plains, a decrease in slope causes reduced velocity, allowing sediments to be deposited within lobes. Construction of the fan is primarily due to the deposition of sediments transported by turbidity currents (Naini and Kolla 1982; Kolla and Coumes 1984). The Indus Fan extends about $1500 \mathrm{~km}$ into the Arabian Sea and is up to $960 \mathrm{~km}$ wide (Naini and Kolla 1982; Kolla and Coumes 1984, 1987).

\section{Datasets}

High resolution swath bathymetry data were acquired onboard ORV Sagar Kanya (SK-306) in 2013 in the eastern Arabian Sea. 2D multi-channel seismic data were collected along four regional lines within the survey block in 2014. Processing and interpretation of this high resolution multibeam and multi-channel seismic data forms the basis of this study. Swath bathymetry data from the eastern Arabian Sea were acquired onboard ORV Sagar Kanya, during a 26 day long cruise SK-306, using a hull-mounted deepwater SB3012 multibeam system. The swept-beam technology provides full motion 
compensation and the system operates at $12 \mathrm{kHz}$ frequency with an effective $150^{\circ}$ of swath and a beam width of $1^{\circ}$, providing coverage over five times the water depth. A total of around 7740 line $\mathrm{km}$ data were collected along 27 track lines, covering an area of $54,253 \mathrm{~km}^{2}$. The multibeam system uses Hydrostar software for data acquisition and C-NAV, dual frequency, DGPS system is used for positioning. Data were processed with EIVA@Nav Editor Software and subsequently exported into ArcGIS v10.2 for creating 2D Digital Bathymetric Model(s) of the survey area and into Fledermaus v7.3.1a for generation of 3D plots. In addition, supporting 2D seismic data were acquired under the International Ocean Discovery Program of India (IODP-India). 2D seismic data of $12 \mathrm{~s}$ Two Way Travel Time (TWT) were acquired along four profiles onboard R/V Geo Hindsagar, with a gun volume of $5500 \mathrm{cu}$ in. at $2000 \mathrm{psi}$ and $6000 \mathrm{~m}$ long streamer. The location of the study area within the Indus Fan system is shown in Fig. 1a. Seismic data were processed up to time migrated stacks using a standard approach prior to interpretation.

\section{Results \\ Morphology}

A bathymetry map of $100 \mathrm{~m}$ grid size (Fig. 2a) and three dimensional images (Fig. 2b) were generated from SB3012 multibeam data. The overall bathymetry is rather gradual with water depths varying from 3000 to $3700 \mathrm{~m}$. The most prominent morphological features are the Laxmi Ridge and Raman Seamount (Figs. 2, 3). The seismic reflection and the multi-beam bathymetry data employed in this study image the Raman Seamount in detail for the first time. The Raman Seamount is a part of NNW-trending linear seamount chain consisting of three major edifices, Raman and Panikkar Seamounts and Wadia Guyot (Bhattacharya et al. 1994). Laxmi Ridge is a NW-SE elongated structure considered to be a continental sliver rifted from India before the Seychelles-India break-up (Naini and Talwani 1982; Biswas 1987; Kolla and Coumes 1990; Talwani and Reif 1998).

The multibeam data presented in this study gives enhanced three-dimensional perspectives of the channel systems in the distal parts of the fan and further allows precise images of the Raman Seamount and Laxmi Ridge. Laxmi Ridge, is $\sim 246 \mathrm{~km}$ long, $86.5 \mathrm{~km}$ wide and on average $835 \mathrm{~m}$ high, covering an area of about 10,640 $\mathrm{km}^{2}$ (Table 1). The N-S elliptical and elongated morphological expression-Raman Seamount is about $49 \mathrm{~km}$ long and $23 \mathrm{~km}$ wide, with an average height of $1371 \mathrm{~m}$, covering a basal area of around $772 \mathrm{~km}^{2}$ (Table 1). Earlier studies reported a secondary peak on the top of the Raman Seamount having basal area of about $28 \mathrm{~km}^{2}$ (Bhattacharya et al. 1994; Iyer et al. 2012). The secondary peak and its basal area $\left(34 \mathrm{~km}^{2}\right)$ measured based on new results are in conformity with the earliest studies (Fig. 3a, b).

\section{Fan sedimentation}

Seismic profiles from the area have been described by Pandey et al. (2015). Seismic profile IODP-04 (Figs. 4, 5) demonstrates the presence of thick upper Miocene and younger strata $(\sim 460 \mathrm{~m})$. The fan in the area of the Laxmi Basin is built up by a series of overlapping distal lobes that are cut by erosive channels, presumably supplying lobes in yet more distal parts of the fan. The lobes do not show well developed aggradation channel levee forms, as better developed in the western and northern Arabian Sea. In those more proximal settings the characteristic triangular cross section of an aggradation channel is clear on seismic (McHargue and Webb 1986; Droz and Bellaiche 1991; Clift et al. 2002) contrasting with the flatter geometries seen in this area. The channels in the sub-surface of the Laxmi Basin moreover incise into the older strata and are often not aggradational, indicating that currents here are less laden with sediments than in more proximal areas. The fact that they are reworking the older strata would result in a recycled sedimentary record downslope that only partly reflects the erosional signal from the source at the time of sedimentation.

\section{Deep-sea channel systems}

A total of five channels have been observed in the area and are shown in Figs. 2 and 6. Channel 2, 3 and section I of Channel 4A (NE of Laxmi Ridge) have a NE-SW orientation, perpendicular to the ridge. The orientations of Channel 1, section II of Channel 4A and Channel 4B follow a track parallel to the Laxmi Ridge. Channel $4 \mathrm{~B}$ could be connected with Channel 4A. We divide Channels 1 and 4A into two sub-sections (I and II) based on a sudden change in orientation. A 3D model of a part of Channel 1 is shown in Fig. 2b. Channel dimensions are computed and listed in Table 2. The total length of all channels along the channel axis is about $915 \mathrm{~km}$, and their width varies from 189 to $1980 \mathrm{~m}$. Channels have an average depth of about $60 \mathrm{~m}$. The longest, Channel 4A, is about $256 \mathrm{~km}$ long, $700 \mathrm{~m}$ wide and about $57 \mathrm{~m}$ deep (Table 2).

\section{Channel morphology and sinuosity}

Cross section profiles were generated to cover the entire channel system (Fig. 6) from the gridded depth data and are shown in Fig. 7 and the "Appendix". A total of 44 profiles are shown, which include eleven profiles from Channel 1, six from Channel 2, nine from Channel 3, fourteen from Channel 4A and four profiles from Channel 4B. The profiles show the channel thalweg, as well as outer levees, channel banks, terraces, stepped terraces, and inner levees. 


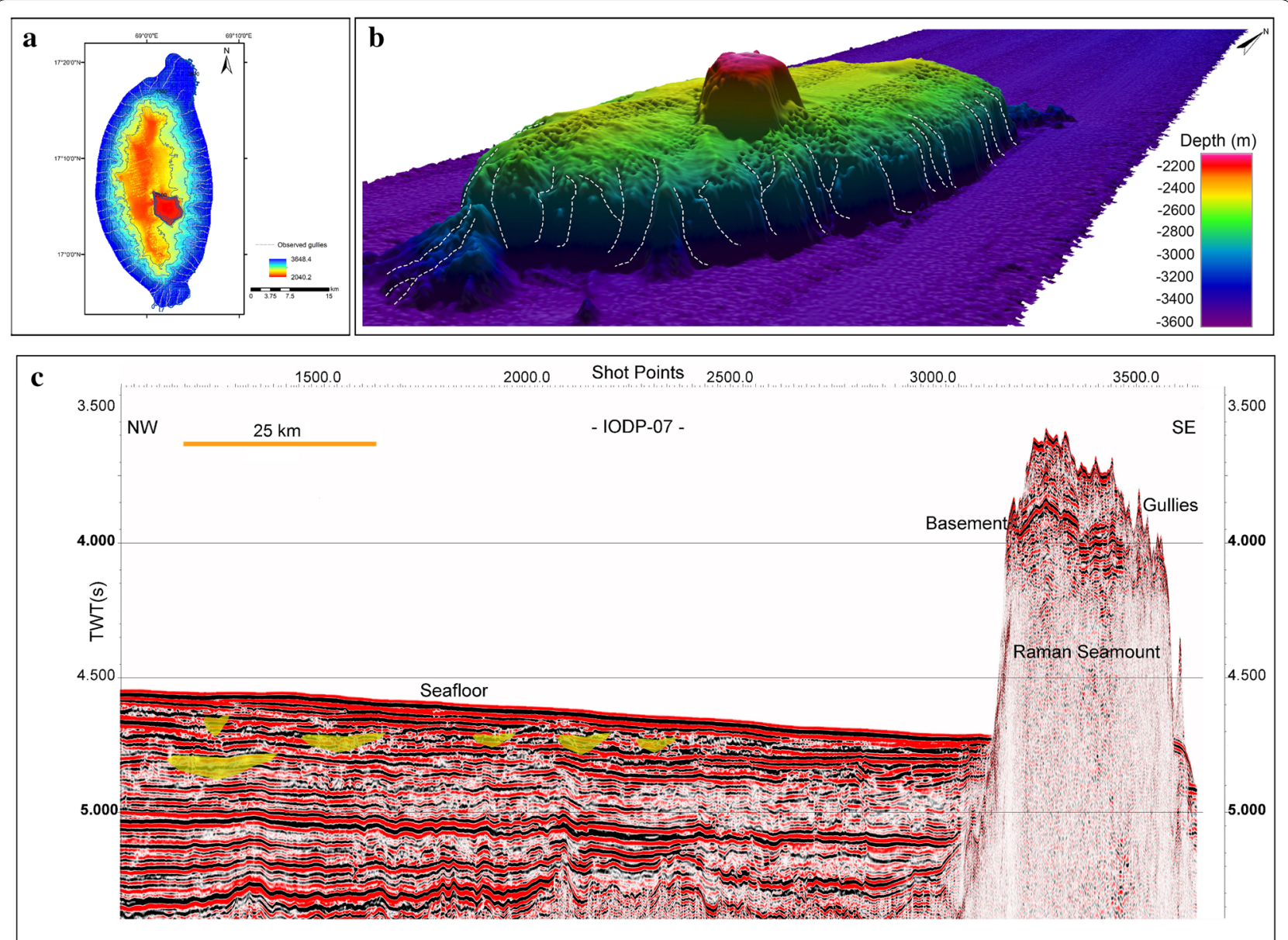

Fig. 3 a 2D image of Raman Seamount with dendritic gully pattern. b 3D image of Raman Seamount with a vantage point of SE-NW. Secondary peak above the plateau of Raman Seamount is depicted. Gully patterns can be seen on the flanks of the feature and marked as dashed lines. c 2D seismic reflection profile (segment AA' from IODP-07; (refer Fig. 2) showing Raman Seamount and presence of various paleo-channels

Table 1 Dimension of the Raman Seamount and Laxmi Ridge based on new data

\begin{tabular}{lll}
\hline Parameters & Raman Seamount & Laxmi Ridge \\
\hline Basal area $\left(\mathrm{km}^{2}\right)$ & 772.07 & $10,640.13$ \\
Basal area of secondary peak $\left(\mathrm{km}^{2}\right)$ & 34.36 & - \\
Plateau area $\left(\mathrm{km}^{2}\right)$ & 208.15 & - \\
Maximum height $(\mathrm{m})$ & 1371 & 835 \\
Length $(\mathrm{km})$ & 48.94 & 246.06 \\
Width $(\mathrm{km})$ & 22.86 & 86.43 \\
\hline
\end{tabular}

Multi-channel seismic (MCS) reflection data have been used to understand the seafloor. The presence of the channels (or the lack thereof) in proximity to major features such as Laxmi Ridge and Raman Seamount is inferred based on apparent incisions in the seismic sections and comparison with the bathymetry maps. Details of gullies (Fig. 3a, b) over the Raman Seamount identified from bathymetric data are well supported by the seismic images (Fig. 3c).

The sinuosity is a function of slope and nature of sediment, with high sinuosity associated with low gradient. The channels are highly sinuous in nature and average channel length is twice the straight channel length. Channel sinuosity varies from 1.55 (Section II of Channel 1) to 3.21 (Channel 3).

\section{Reconstruction of the Indus Fan channel system}

Channels of the Indus Fan have already been reconstructed west of Laxmi Ridge (Kenyon et al. 1995; Prins et al. 2000), while we now show the presence of channels to the east of Laxmi Ridge. New channels identified are traced back and connected to the upper fan system using the previous data, as well as satellite gravity derived bathymetry data (Fig. 1b). Channel patterns on the Indus Fan are discussed in detailed by Prerna et al. (2015). 


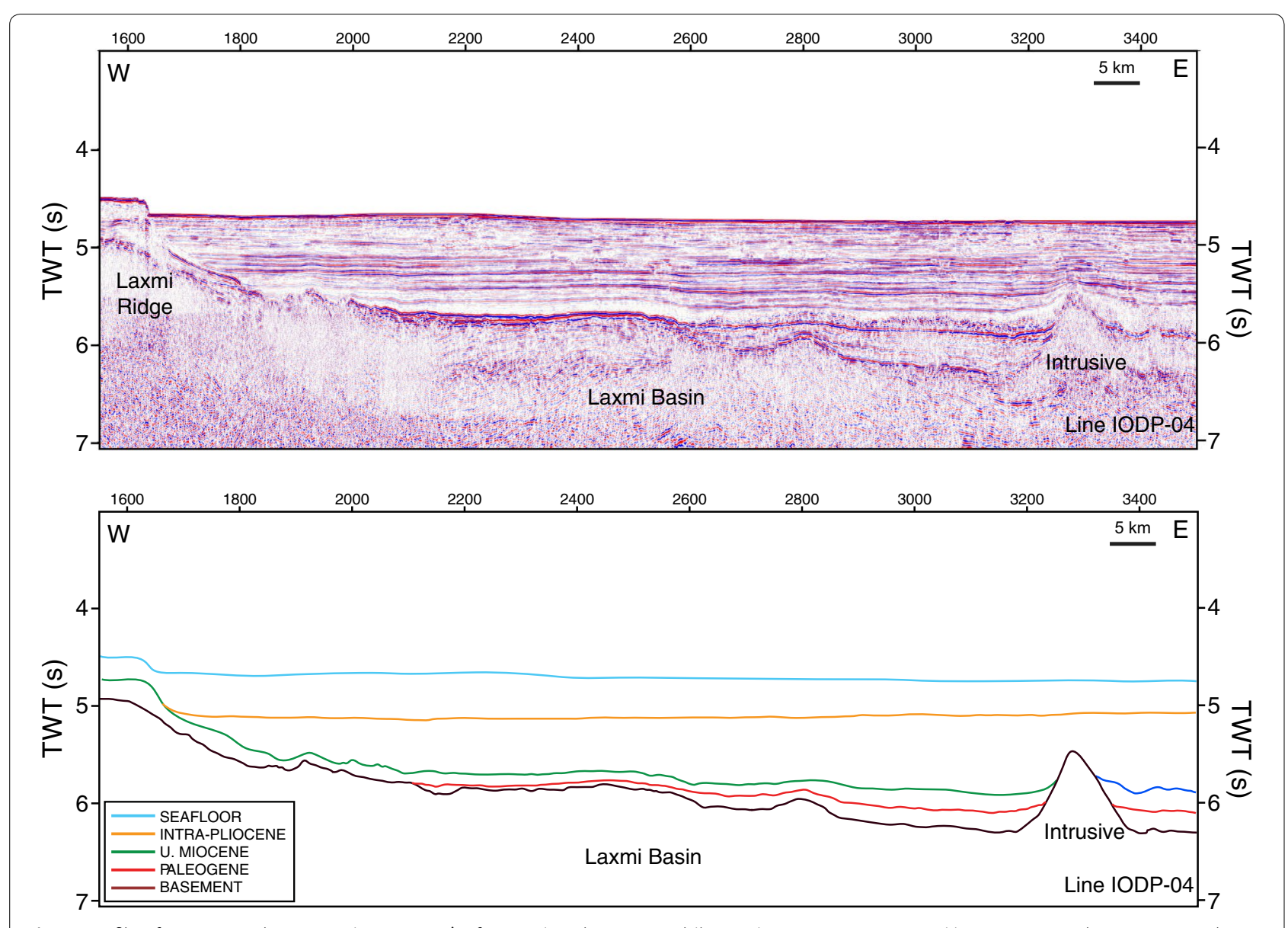

Fig. 4 Profile of seismic track IODP-04 (Section AA' refer Fig. 2) and interpreted (bottom) seismic section. TWT(s) two-way travel time in seconds

The channels imaged here are part of the Indus system and may not be connected with other Indian River systems emanating from the WCMI. Many rivers like the Narmada and Tapti flow into the Arabian Sea from the peninsular but no active canyon-channel system has yet been identified. This contrasts with the western Arabian Sea (NW of Murray Ridge), where many small active canyon-channel systems have been observed (Bourget et al. 2011). The reason for the lack of flow from peninsular India may be attributed to the extremely broad shelf on the western continental margin with comparatively low sediment flux from these rivers causing the lack of canyon-channel system development on the slope, although these rivers are reported to have some offshore extension (Vora et al. 1991). The active channel system of the area mapped in this study shows the eastward extension of the Indus channel system into the middle fan area, and confirms the sediment supply through the shelf region to middle fan area (Fig. 1b).

\section{Discussion}

Indus submarine channel is a sinuous channel system similar to many other modern submarine systems, such as the Amazon, Bengal and Zaire (Clark et al. 1992; Peakall et al. 2012; Wynn et al. 2007). The variations in channel morphology from north to south are notably influenced by the Laxmi Ridge. The channels north of Laxmi Ridge are more sinuous than those to the east of the ridge (Figs. 2, 6; section II of Channel 1 and 4A and Channel 4B). The east-west slope of Laxmi Ridge influences the flow by guiding channels along the ridge trend, i.e. flowing parallel to the ridge as they approach it. The east-west slope of the ridge also restricts expansion of meanders and consequently the channels have comparatively low radii of curvature. These variations on the flow pattern can be attributed to the morphological dominance of the Laxmi Ridge. In this respect these channels mimic those observed in the Austrian Molasse basin in which the topography on the edge of the basin plays a 


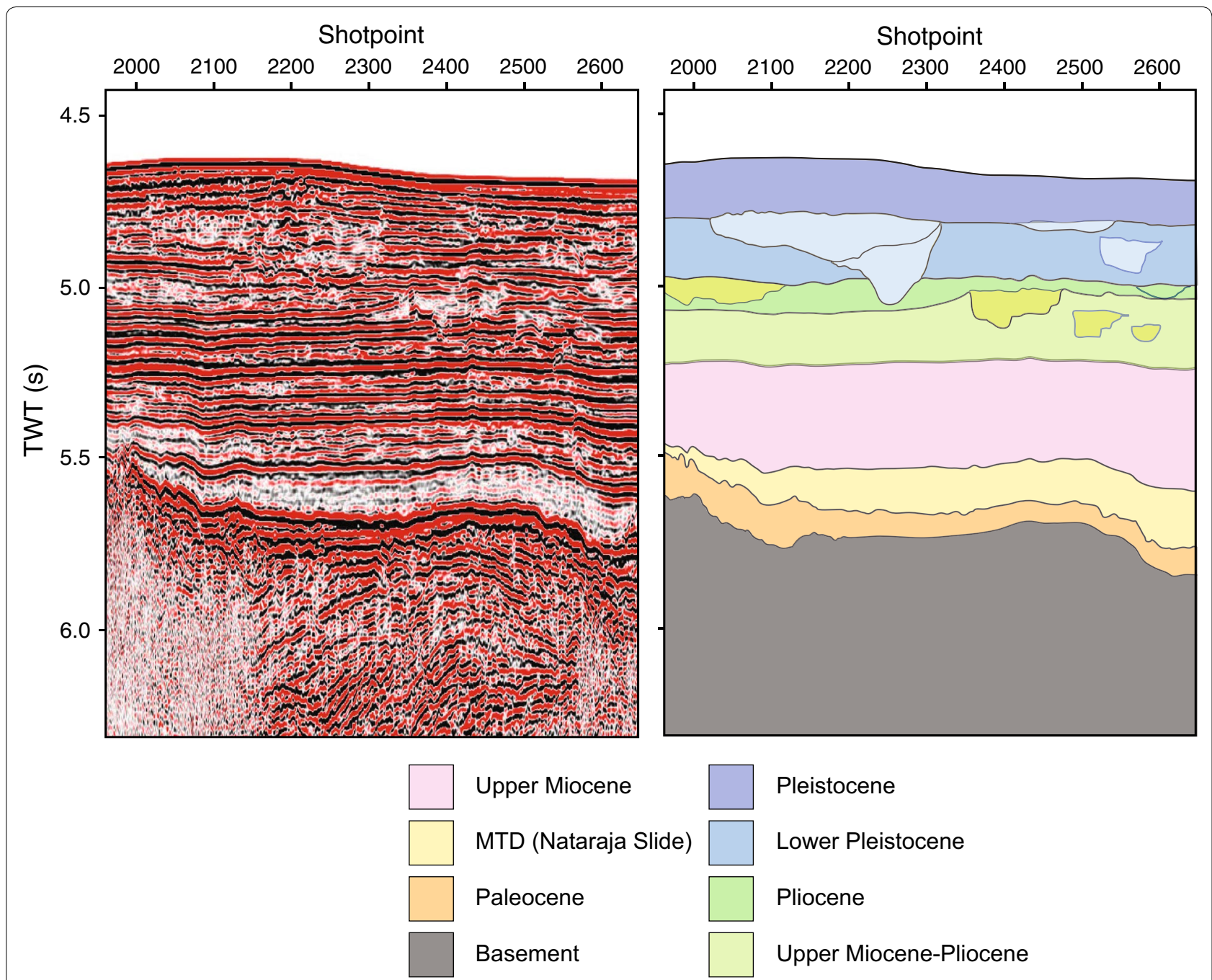

Fig. 5 Close-up (left) and interpretation (right) of seismic profile IODP-04 (Section CC') showing the major seismic units identified in IODP-355 drilling. The sections show large channels in the Pleistocene section. MTD mass transport deposit. The different colours represent resolvable seismic units

strong role in guiding the orientation of the channels and in turn controlling long-term distribution of sediment types (Hubbard et al. 2009). The similar impact are also observed in African Angola basin (Gee and Gawthorpe 2006). The guiding influence of Laxmi Ridge is also apparent over long geological time periods as revealed by IODP drilling that shows a preferential development of coarser sediments in the basin center and finer lithologies more associated with distal overbank deposits closer to the edge of Laxmi Ridge itself (Pandey et al. 2015).

Channels $4 \mathrm{~A}$ and $4 \mathrm{~B}$ were likely connected in the recent past and it seems likely that several of the channels present state represents avulsion events. Channel 2 likely formerly connected to Channel 1 , while Channel 3 ends against the edge of Laxmi Ridge and must have been diverted south in the past potentially connecting with Channel $4 \mathrm{~B}$ before the initiation of Channel 4A. The Indus channels show similarities with punctuated channel migration history of the Lucia Chica Channel offshore California in which channel migration was not continuous but occurred in a number of discrete steps (Maier et al. 2012; Fildani et al. 2013).

The steepest gradient in this study is observed in the channels flowing in the vicinity of the Laxmi Ridge (Fig. 6; section II of Channels 1 and 4A) with comparatively low degrees of meandering. The steep slope at the foot of Laxmi Ridge and its adjoining area, along with the slope gradient of the channel together control channel flow and the meandering in the vicinity of the ridge. The morphology of the channel banks is characterized by steep to gentle slopes, while the inner banks are 


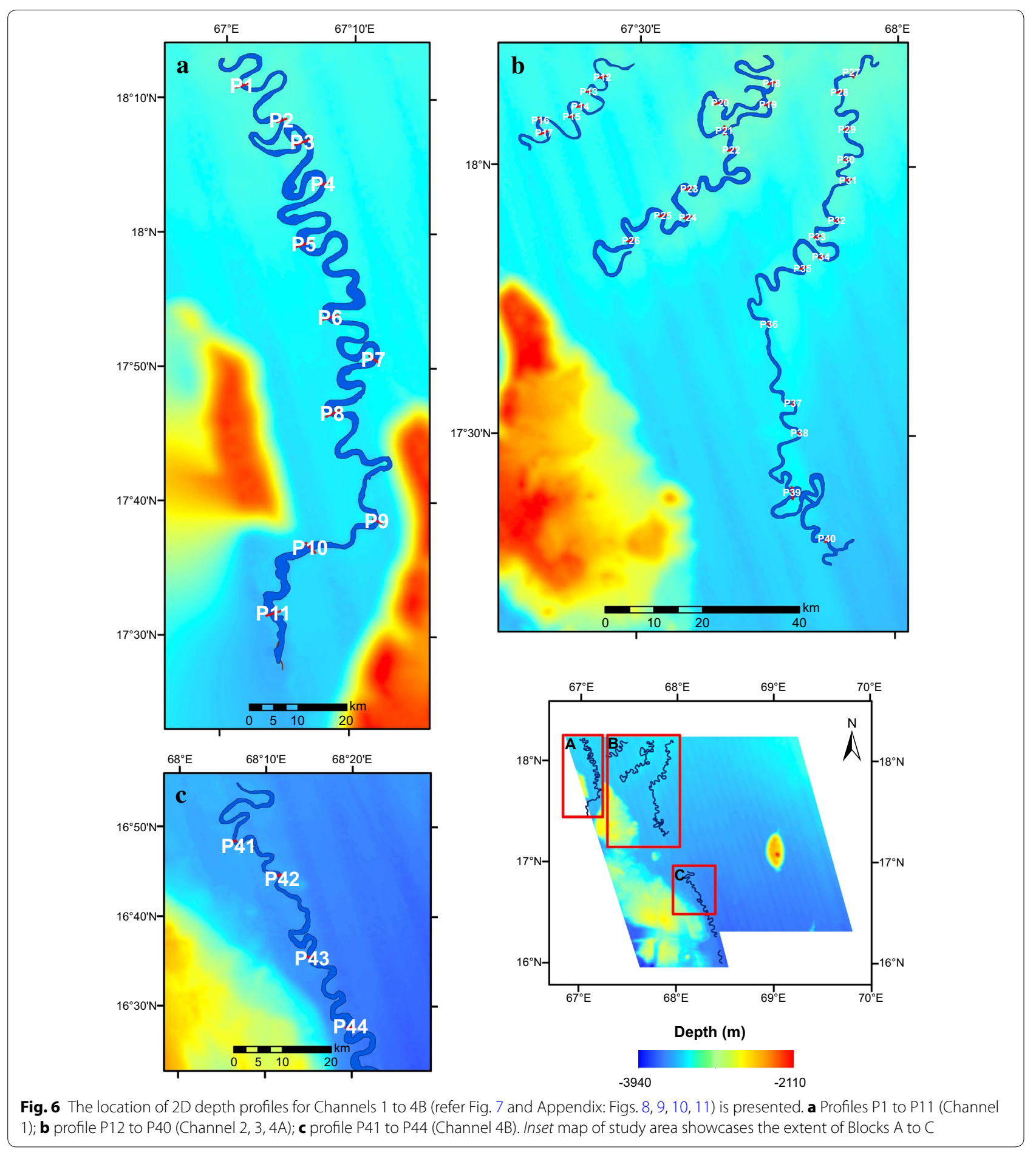

frequently marked by the presence of one or several small terraces (Fig. 7 and "Appendix").

Channel morphology and dimensions typically exhibit the channel characteristics of the middle Indus Fan, as described by Kolla and Coumes (1987) and Wynn et al. (2007). In general the maximum width of the channels is present in the upper fan area and because the gradient decreases southward, the channel widths and depths also decrease towards the lower fan. Channels were previously reported to be $10 \mathrm{~km}$ wide in the upper fan area, whereas in the lower fan, channels are $<1.5 \mathrm{~km}$ wide and $<5$ m deep (Wynn et al. 2007). In all systems, channel 
Table 2 Dimension of the Indus channel system in the area

\begin{tabular}{|c|c|c|c|c|c|c|c|c|c|}
\hline \multirow{2}{*}{$\begin{array}{l}\text { Indus chan- } \\
\text { nel system }\end{array}$} & \multicolumn{3}{|l|}{ Channel 1} & \multirow[t]{2}{*}{ Channel 2} & \multirow[t]{2}{*}{ Channel 3} & \multicolumn{3}{|l|}{ Channel 4A } & \multirow[t]{2}{*}{ Channel 4B } \\
\hline & Total & Section I & Section II & & & Total & Section I & Section II & \\
\hline $\begin{array}{l}\text { Channel axis } \\
\text { length }(\mathrm{km})\end{array}$ & 226.06 & 171.42 & 54.63 & 69.54 & 179.36 & 256.30 & 121.31 & 120.49 & 183.62 \\
\hline $\begin{array}{l}\text { Downstream } \\
\text { straight } \\
\text { distance } \\
(\mathrm{km})\end{array}$ & 89.42 & 54.14 & 35.28 & 27.67 & 55.81 & 112.30 & 55.69 & 56.61 & 79.04 \\
\hline Sinuosity & 2.53 & 3.17 & 1.55 & 2.51 & 3.21 & 2.28 & 2.18 & 2.12 & 2.32 \\
\hline $\begin{array}{l}\text { Slope } \\
\text { gradient of } \\
\text { channel }\end{array}$ & $1: 511$ & $1: 694$ & $1: 368$ & $1: 864$ & $1: 649$ & $1: 702$ & $1: 831$ & 1:1029 & $1: 564$ \\
\hline $\begin{array}{l}\text { Width range } \\
\text { (m) }\end{array}$ & $\begin{array}{l}352.67- \\
1873.49\end{array}$ & $\begin{array}{l}352.67- \\
1873.49\end{array}$ & $\begin{array}{l}418.92- \\
1775.93\end{array}$ & $\begin{array}{r}189.81- \\
657.84\end{array}$ & $\begin{array}{l}460.71- \\
1290.95\end{array}$ & $\begin{array}{l}274.67- \\
1147.36\end{array}$ & $\begin{array}{r}274.67- \\
939.65\end{array}$ & $\begin{array}{c}526.84- \\
1174.36\end{array}$ & $\begin{array}{l}412.54- \\
1980.49\end{array}$ \\
\hline $\begin{array}{l}\text { Depth range } \\
\text { (m) }\end{array}$ & 19.66-95.33 & $26.37-90.62$ & $19.66-95.33$ & $9.33-28.66$ & $36.55-71.44$ & $20.66-82.8$ & $20.66-58.33$ & $25.2-82.8$ & $7.5-91.5$ \\
\hline $\begin{array}{l}\text { Avg. depth } \\
\text { of channel } \\
\text { (m) }\end{array}$ & 66.42 & 61.85 & 70.99 & 52.16 & 55.69 & 57.45 & 60.51 & 54.44 & 58.68 \\
\hline
\end{tabular}

widths and depths decrease downstream (Normark 1985), which is also true for the channels mapped here.

The Raman Seamount shows gullies and a secondary peak (Fig. 3). The flat surfaces appears to have been formed either by erosional wave planation effects or by constructional volcanic processes (Fornari and Ryan 1984; Bhattacharya et al. 1994), while extensive gully features are likely the product of submarine erosional processes (Kenyon et al. 1978; Lonsdale et al. 1972). If the Raman Seamount is a similar age of the rest of Laxmi Basin then simple oceanic thermal subsidence of $\sim 2800 \mathrm{~m}$ since $65 \mathrm{Ma}$ (Parsons and Sclater 1977) would place the top of the seamount (now at $\sim 2100 \mathrm{~m}$ water depth; Fig. 3) above sea level at the time of its initial eruption. Thus wave cutting would be a possible explanation for the remarkably flat top of the seamount.

The dendritic gully pattern over the seamount resembles a relict drainage pattern of subaerial erosional origin but these gullies must be submarine because drilling of the basement at IODP Sites U1456 and U1457 adjacent to Laxmi Ridge and Raman Seamount indicates consistent deep-water conditions that preclude subaerial emergence of the seamount in recent times (Pandey et al. 2015). Similar systems have been noted in other continental margin settings, such as California (Pratson and Ryan 1996), Central Atlantic America (Vachtman et al. 2013), Chile (Bernhardt et al. 2015) and Taiwan (Ramsey et al. 2006), where the channels are all clearly formed by submarine processes alone. Vachtman et al. (2013) hypothesize that a concave hypsometry is characteristic of erosion by sedimentary flows, spilling over the shelf edge. In contrast a convex hypsometry that dendritic networks, originating at or below the shelf break, as we see in this study, is attributed to retrograde erosion as a result of headward erosion driven by mass wasting.

The youngest sediments in Laxmi Basin are muddy and carbonate rich, whereas older sequences are sandy sheetlike deposits. The initial results at IODP Sites U146 and U1457 indicate the top $70 \mathrm{mts}<1.2 \mathrm{Ma}$, spanning much of the Pleistocene (Pandey et al. 2015), during which time there have been many sea-level cycles and plenty of opportunities for the accumulation of "low stand" fan deposits. Since 1.2 Ma the active lobes of the Indus Fan have been located west of Laxmi Ridge, allowing a dominantly muddy and hemipelagic sequence to accumulate (Pandey et al. 2015).

\section{Conclusions}

This study presents a detailed mapping of new channel systems in the eastern middle Indus Fan and for the first time highlights the pathways of Indus Canyon-channel system, on the eastern side of Laxmi Ridge. The morphometric analyses confirm that the channels observed are fed by the currently active Indus Canyon-channel

(See figure on next page.)

Fig. 7 Profiles P1 to P11 showing the morphological behaviour of Channel 1. The channel notably gains gradient from north to south as can be observed from the profile views. Typical depositional features like stepped terraces, levees and point bars are clearly visible. (OL outer levees, IL inner levees) 

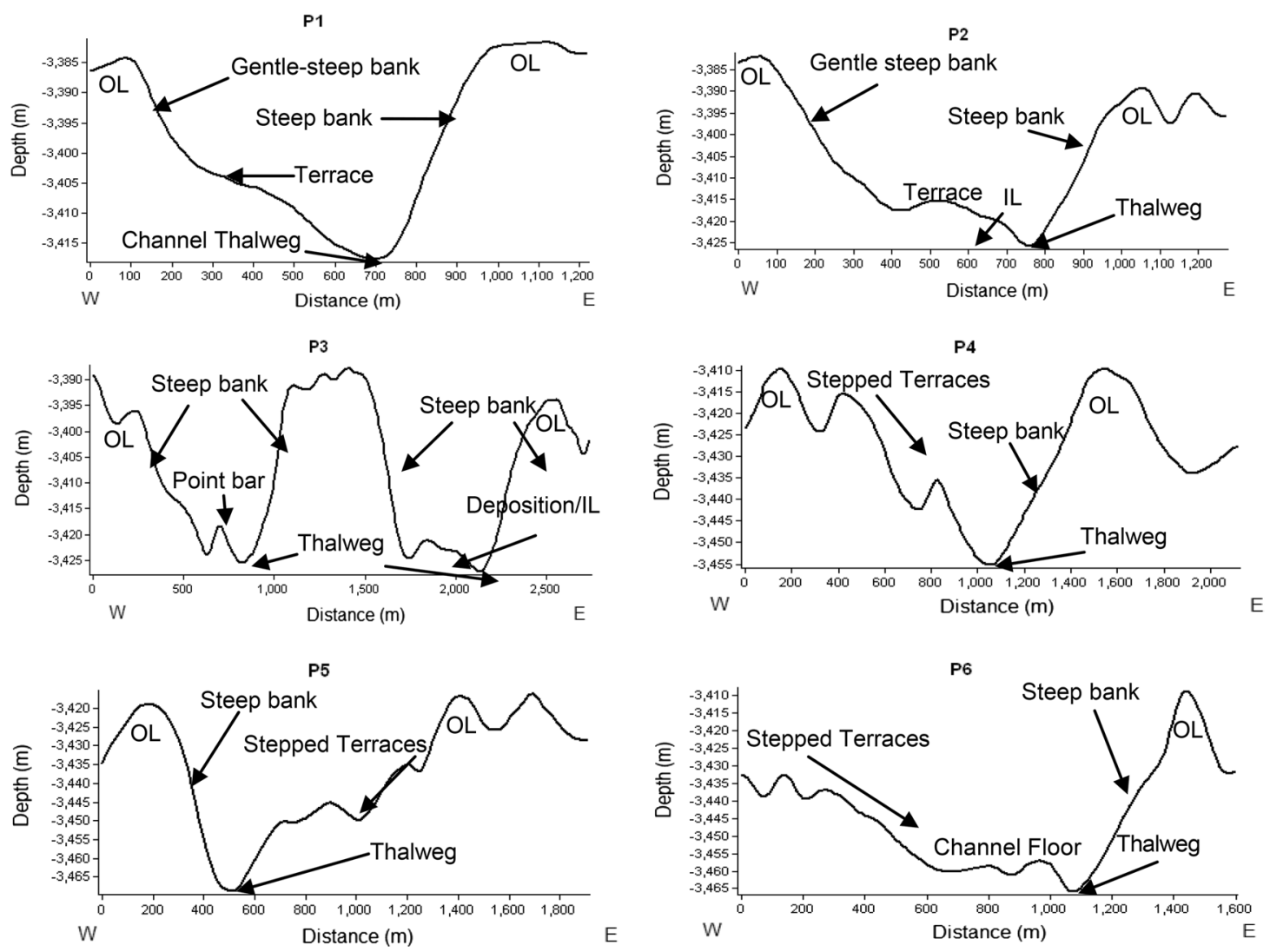

P7

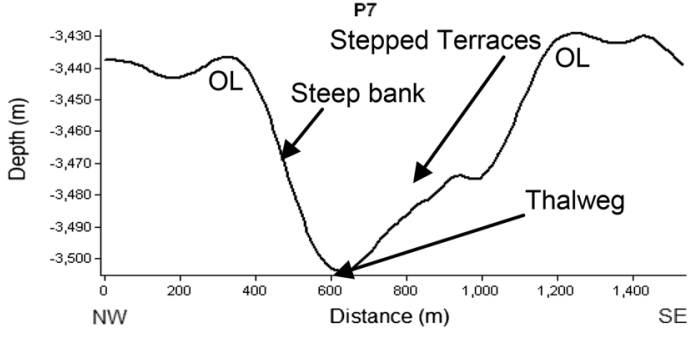

P8
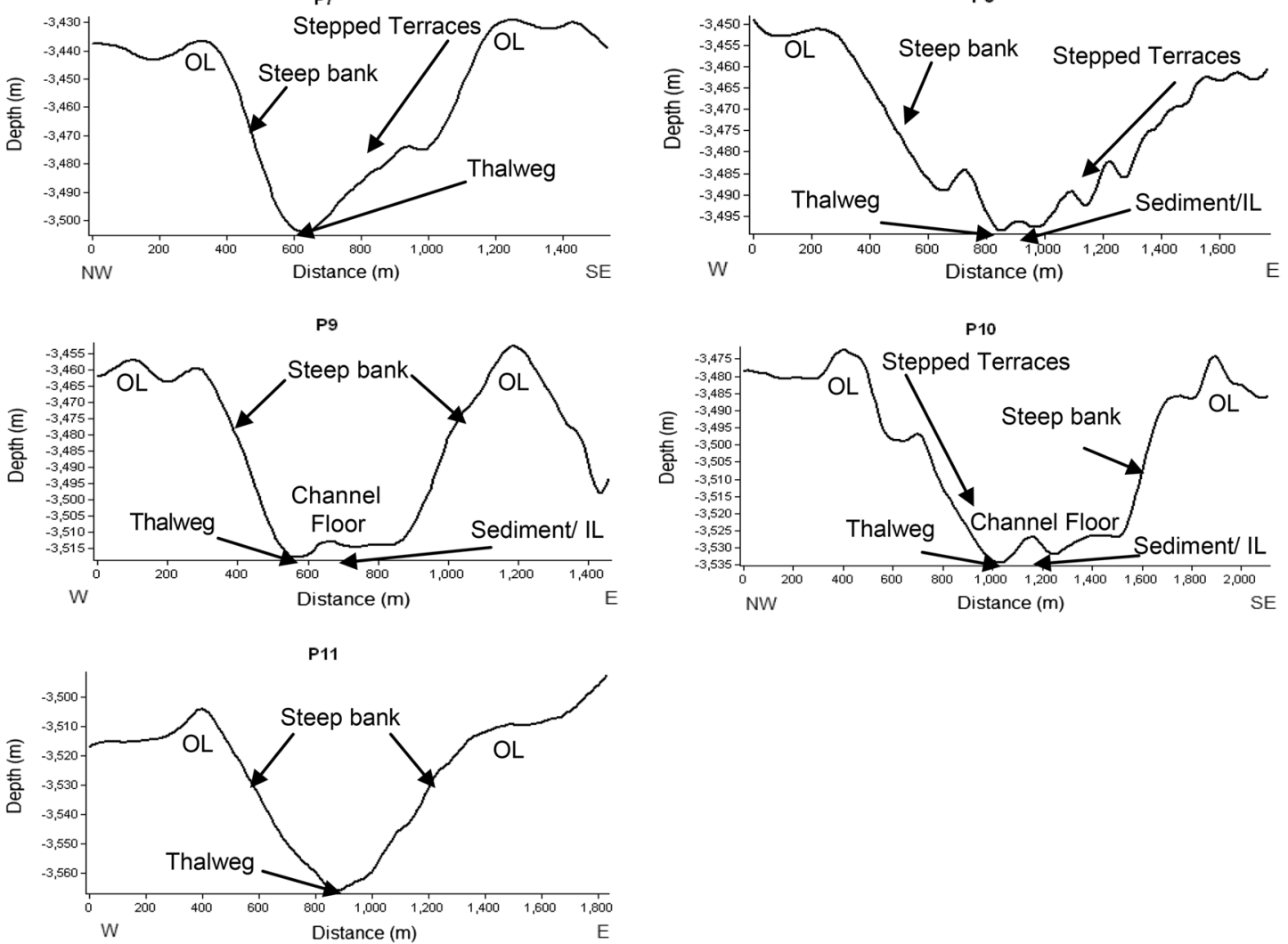
complex system and become less sinuous going south as they are guided in their trajectory by the mass of the Laxmi Ridge. The channels are inferred to be in the mature stage based on their high sinuosity. The origin of the newly discovered channels has been traced back through the middle and upper Indus Fan channel systems using flow accumulation and flow direction modelling in conjunction with the regional bathymetry data. They are not all connected and are likely to be the products of punctuated avulsion events. They are not fed by rivers flowing from western India and are most likely the modern equivalents of erosive channels seen in the Pliocene-recent sub-surface. These channels have the capacity to recycle significant amounts of sediment and may contribute to the loss of erosional signal between the river mouth and the deep abyssal seafloor. The presence of the active channels beyond $68^{\circ} \mathrm{E}$ indicates an eastward extension of the Indus Canyon-channel system. Bathymetric mapping has further imaged the Raman Seamount, which is a flat topped feature with a prominent secondary peak. Simple subsidence estimates indicate the flat top might be linked to wave-cutting shortly after emplacement. However, dendritic channels around the edge of the seamount likely reflect the influences of mass wasting and headward erosion in a purely marine setting.

\section{Authors' contributions}

RM: Survey Planning, Carried out survey as chief scientist, primary data processing, and interpretation and preparation of MS. DKP: Group leader involved in survey planning and preparation of MS. RP: Participated in survey, preparation of maps and involved in preparation of MS. PDC: Discussion and interpretation, involved in preparation of MS. All authors read and approved the final manuscript.

\section{Author details}

${ }^{1}$ IODP-India, National Centre for Antarctic and Ocean Research, Headland Sada, Vasco-Da-Gama, Goa 403804, India. ${ }^{2}$ National Centre for Antarctic and Ocean Research, Headland Sada, Vasco-Da-Gama, Goa 403804, India. ${ }^{3}$ Department of Geology and Geophysics, Louisiana State University, Baton Rouge, LA 70803, USA

\section{Acknowledgements}

Authors would like to thank Director, National Centre for Antarctic and Ocean Research (NCAOR), Goa for allocating Cruise time onboard ORV Sagar Kanya (SK-306) as well as the encouragement and support to publish this work. We also thank onboard team of the cruise SK-306 and Geo Hindsagar, including the Master, and crew members onboard for their supreme co-operation during the cruise. Involvement of PD Clift was made possible thanks to the Charles T. McCord Chair in Petroleum Geology. This is NCAOR contribution no. 23/2016.

\section{Competing interests}

We have utilised our own Institute Research Vessel ORV Sagar Kanya for multibeam survey. The seismic survey is part of my institute survey done in the charted vessel R/V Geo Hindsagar. All financial and other supports are from my Institute "National Centre for Antarctic and Ocean Research, Ministry of Earth Sciences".

\section{Appendix}

See Figs. 8, 9, 10, 11. 


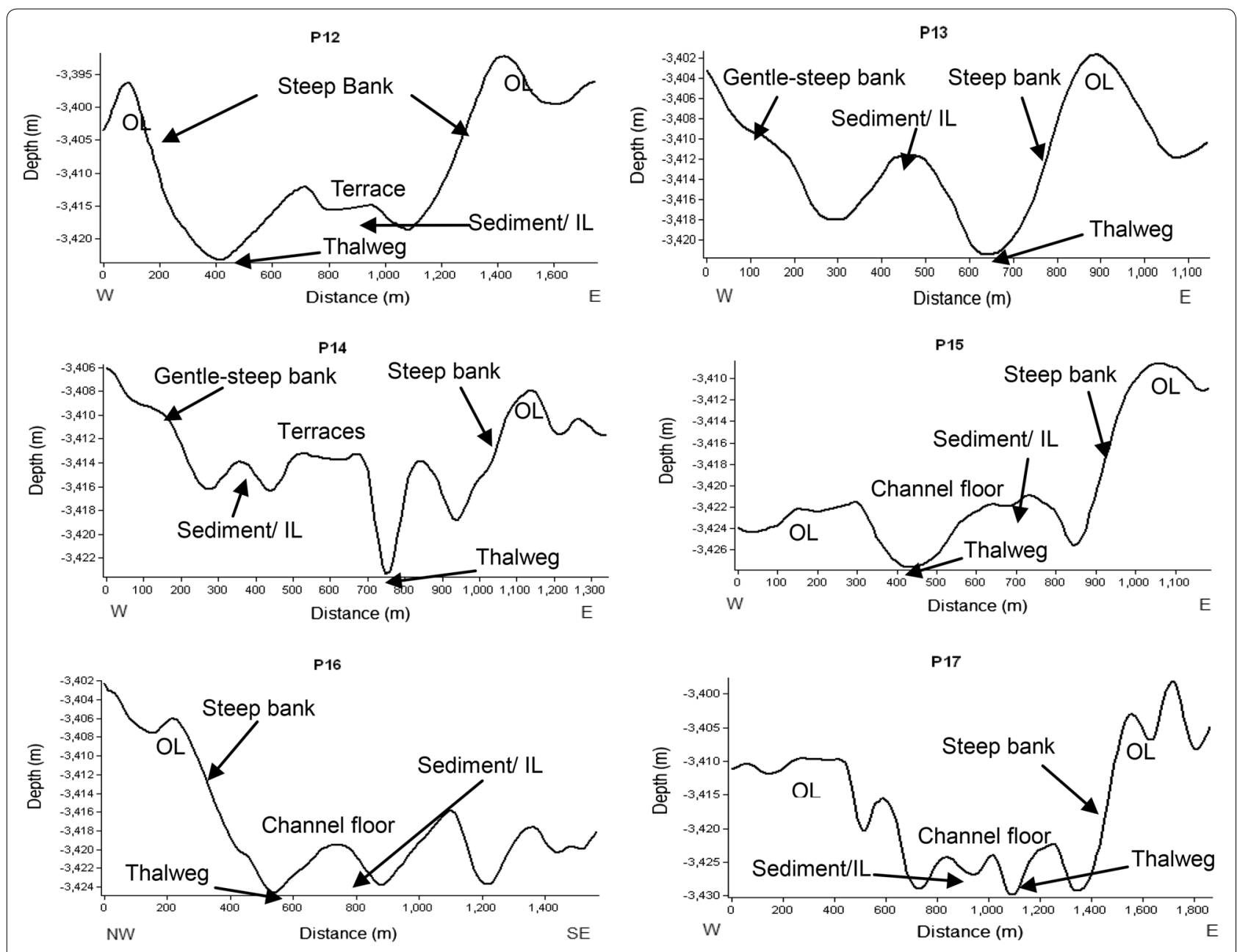

Fig. 8 Profiles P12 to P17 showing the morphological behaviour of Channel 2. This channel shows marked variability in its internal structure and follows a NE-SW trend. Typical depositional features like stepped terraces, levees and point bars are clearly visible (OL outer levees, IL inner levees) 

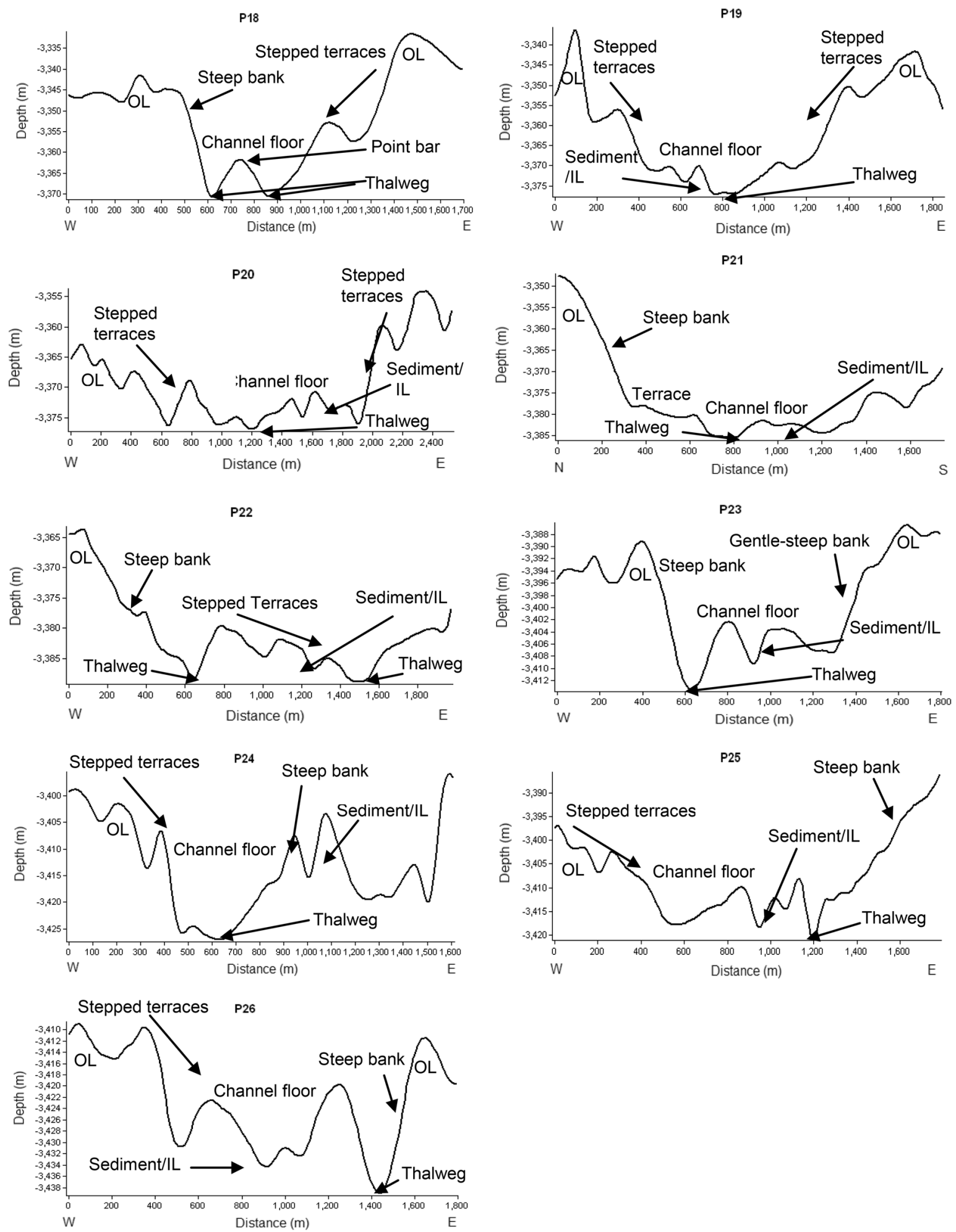

Fig. 9 Profiles P18 to P26 showing the morphological behaviour of Channel 3. This channel follows a broader width as opposed to other channels, also following a NE-SW trend. Typical depositional features like stepped terraces, levees and point bars are clearly visible. (OL outer levees, IL inner levees) 

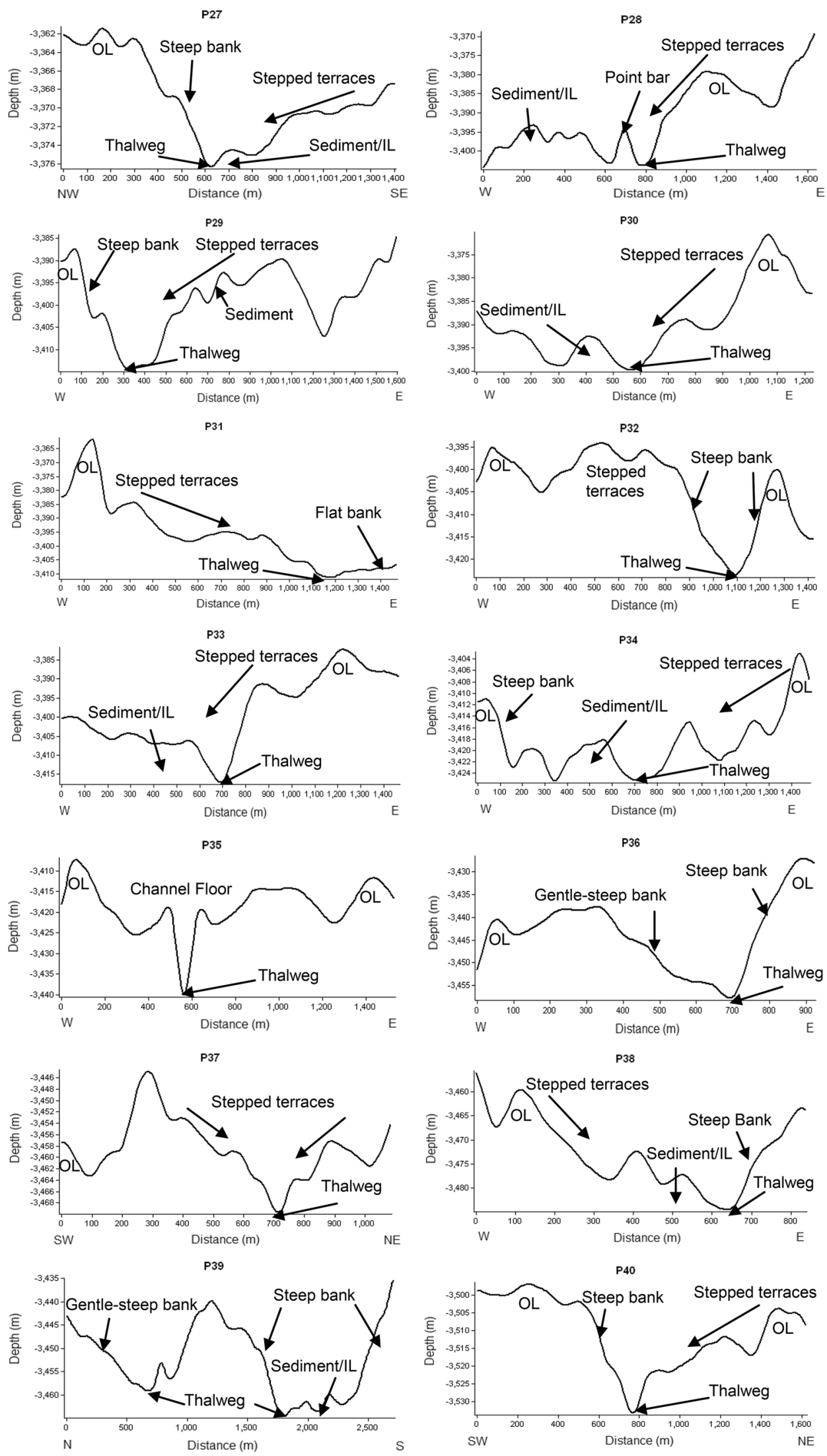
(See figure on previous page.)

Fig. 10 Profiles P27 to P40 showing the morphological behaviour of Channel 4A. Initially flowing from NW-SE, the channel shifts near P36 to follow a more NNW-SSE trend. A higher gradient, similar to the behaviour of Channel 1 can be noted. Typical depositional features like stepped terraces, levees and point bars are clearly visible. (OL outer levees; IL inner levees)

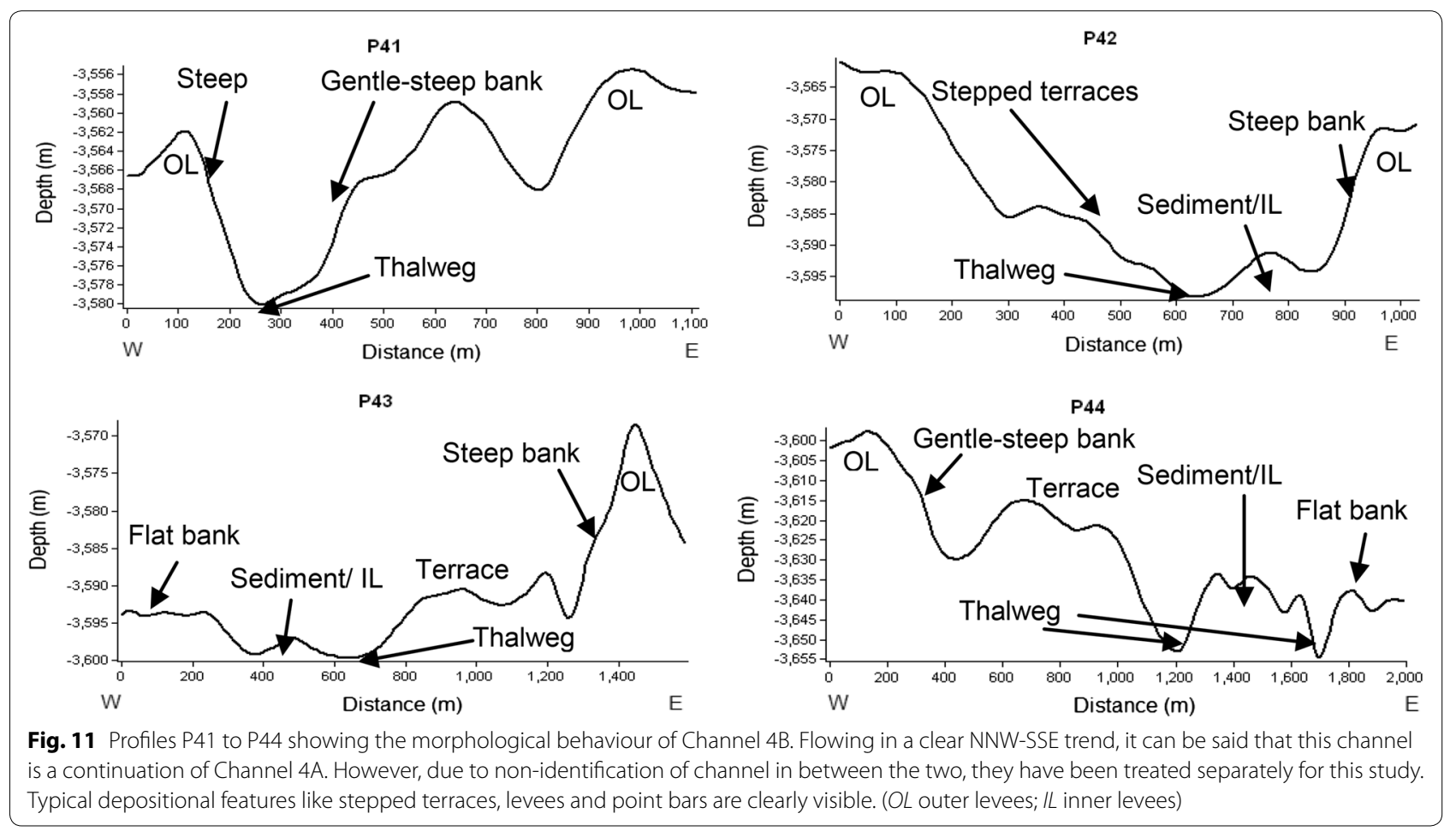

Received: 22 October 2015 Accepted: 2 June 2016

Published online: 23 June 2016

\section{References}

Babonneau N, Savoye B, Cremer M, Klein B (2002) Morphology and architecture of the present canyon and channel system of Zaire deep-sea fan. Mar Petrol Geol 19:445-467

Basu S, Gairola RM, Pandey PC (1994) Remote sensing of seamounts in the Central Indian Ocean basin using satellite altimetry. Remote Sens Rev 9:187-202

Bernhardt A, Melnick D, Jara-Muñoz J, Argandoña B, González J, Strecker MR (2015) Controls on submarine canyon activity during sea-level highstands: the Biobío canyon system offshore Chile. Geosphere 11:1226-1255

Bhattacharya GC, Subrahmanyam V (1991) Geophysical study of a seamount located on the continental margin of India. Geo-Mar Lett 21:159-167

Bhattacharya GC, Murthy GPS, Srinivas K, Chaubey AK, Sudhakar T, Nair RR (1994) Swath bathymetry investigation of the seamounts located in the Laxmi basin, eastern Arabian Sea. Mar Geodesy 17:169-182

Biswas SK (1987) Regional tectonic framework, structure and evolution of the western marginal basins of India. Tectonophysics 135:307-327

Bouma AH, Normark WR, Bames NE (1985) Submarine fans and related turbidite systems. Springer, New York, p 351

Bourget J, Zaragosi S, Ellouz-Zimmermann S, Ducassou E, Prins MA, Garlan T (2010) High stand vs. low stand turbidite system growth in the Makran active margin: imprints of high frequency external controls on sediment delivery mechanisms to deep water systems. Mar Geol 274:187-208
Bourget J, Zaragosi S, Ellouz-Zimmermann N, Mouchot N, Garlan T, Jean-Luc S, Lanfumeym V, Lallemant S (2011) Turbidite system architecture and sedimentary processes along topographically complex slopes: the Makran convergent margin. Sedimentology 58(2):376-406

Bourget J, Zaragosi S, Rodriguez M, Fournier M, Garlan T, Chamot-Rooke N (2013) Late Quaternary mega turbidites of the Indus Fan: origin and stratigraphic significance. Mar Geol 336:10-23

Castelltort S, Van Den Driessche J (2003) How plausible are high-frequency sediment supply-driven cycles in the stratigraphic record? Sed Geol 157:3-13

Clark JD, Kenyon NH, Pickering KT (1992) Quantitative analysis of the geometry of submarine channels: implications for the classification of submarine fans. Geology 20:633-636

Clift PD (2002) A brief history of the Indus River. In: Clift PD, Kroon D, Craig J, Gaedicke C (Eds) The tectonics and climatic evolution of the Arabian Sea Region. Geol Soc London Spec Pub 195:237-258

Clift PD, Giosan L (2014) Sediment fluxes and buffering in the post-glacial Indus Basin. Basin Res 26:369-386. doi:10.1111/bre.12038

Clift PD, Shimizu N, Layne GD, Blusztajn JS, Gaedicke C, Schlüter HU, Clark MK, Amjad S (2001) Development of the Indus Fan and its significance for the erosional history of the Western Himalaya and Karakoram. Geol Soc Am Bull 114:1039-1051

Clift P, Gaedicke C, Edwards R, Lee Jae II, Hildebrand P, Amjad S, White RS Schlüter HU (2002) The stratigraphic evolution of the Indus Fan and the history of the sedimentation in the Arabian Sea. Mar Geophys Res 23:223-245

Clift PD, Giosan L, Henstock T, Tabrez AR (2014) Sediment storage and reworking on the shelf and in the Canyon of the Indus River-Fan system since the Last glacial maximum. Basin Res 26:183-202. doi:10.1111/bre.12041 
Covault JA (2011) Submarine fans and canyon-channel systems: a review of processes, products and models. Nat Educ Knowl 3(10):4

Covault JA, Shelfe E, Traer M, Hubbard SM, Romans BW, Fildani A (2012) Deepwater channel run-out length: insights from seafloor geomorphology. J Sed Res 82:25-40

Curray JR, Emmel FJ, Moore DG (2003) The Bengal fan: morphology, geometry, stratigraphy, history and processes. Mar Petrol Geol 19:1191-1223

Damuth JE, Kolla V, Flood RD, Kowsmann RO, Monteiro MC, Gorini MA, Palma JJC, Belderson RH (1983) Distributary channel meandering and bifurcation patterns on the Amazon deep sea fan as revealed by long range side scan sonar (GLORIA). Geology 11:9498

Das P, lyer SD, Kodagali VN (2007) Morphological characteristics and emplacement mechanism of the seamount in the Central Indian Ocean Basin. Tectonophysics 443:1-18

De Ruig MJ, Hubbard SM (2006) Seismic facies and reservoir characteristics of a deep marine axial channel belt in the Molasse Basin, Puchkirchen Formation, Upper Austria. AAPG Bull 90:735-752

Deptuck ME, Steffens GS, Barton M, Pirmez C (2003) Architecture and evolution of upper fan channel-belt on the Niger Delta slope and in the Arabian Sea. Mar Petrol Geol 20:649-676

Dewey JF, Bird JM (1970) Mountain belts and the new global tectonics. J Geophy Res 75(1):2625-2647

Droz L, Bellaiche G (1991) Seismic facies and geologic evolution of the central portion of the Indus Fan. In: Link MH, Weimer P (eds) Seismic facies and sedimentary processes of submarine fans and related systems. Springer, New York, pp 383-402

Fildani A, Hubbard SM, Covault JA, Maier KL, Romans BW, Traer M, Rowland JC (2013) Erosion at inception of deep-sea channels. Mar Petrol Geol 41:48-61. doi:10.1016/j.marpetgeo.2012.03.006

Fornari DJ, Ryan WBF (1984) The evolution of craters and calderas on young seamounts: insight from Sea MARC I and Sea Beam sonar surveys of a small seamount group near the axis of the East Pacific Rise at $\sim 10^{\circ} \mathrm{N}$. J Geophys Res 89(B13):11069-11083

Fournier M, Chamot-Rooke N, Petit C, Fabbri O, Huchon P, Maillot B (2008) In situ evidence for dextral active motion at the Arabia-India plate boundary. Nat Geosci 1:54-58

Fournier M, Chamot-Rooke N, Rodriguez M, Huchon P, Petit C, Beslier MO, Zaragosi S (2011) Owen fracture zone: the Arabia-India plate boundary unveiled. Earth Planet Sci Lett 320:247-252

Gee MJR, Gawthorpe RL (2006) Submarine channels controlled by salt tectonics: examples from 3D seismic data offshore Angola. Mar Pet Geol 23:443-458

Gorsline DS (1970) Submarine canyons: an introduction. Mar Geol 8:183-186

Griggs GB, Kulm LD (1970) Physiography of Cascadia deep-sea channel. Northwest Sci 44(2):82-94

Hartmann H, Andresky L (2013) Flooding in the Indus basin - a spatiotemporal analysis of precipitation records. Glob Planet Change 107:25-35

Hillier JK, Watts AB (2007) Global distribution of seamounts from ship-track bathymetry data. Geophys Res Lett 34(13):5. doi:10.1029/2007GL029874

Hubbard SM, de Ruig MJ, Graham SA (2009) Confined channel-levee complex development in an elongate depo-center: deep-water Tertiary strata of the Austrian Molasse basin. Mar Pet Geol 26(1):85-112. doi:10.1016/j.marpetgeo.2007.11.006

Inam A, Clift PD, Giosan L, Tabrez AR, Tahir M, Rabbani MM, Danish M (2007) The geographic, geological and oceanographic setting of the Indus River. In: Gupta A (ed) Large rivers: geomorphology and management. Wiley, Chichester, pp 333-345

Iyer SD, Das P, Kalangutkar NG, Mehta C (2012) Seamounts-windows of opportunities and the Indian scenario. Curr Sci 102(10):1382-1391

Jerolmack DJ, Paola C (2010) Shredding of environmental signals by sediment transport. Geophys Res Lett. doi:10.1029/2010GL044638

Kamesh Raju KA, Ramprasad T, Kodagali VN, Nair RR (1993) Multibeam bathymetric, gravity and magnetic studies over $79^{\circ} \mathrm{E}$ fracture zone, Central Indian Basin. J Geophys Res 98(B6):9605-9618

Kenyon NH, Belderson RH, Stride AH (1978) Channels, canyons and slump folds on the continental slope between south-west Ireland and Spain Oceanol Acta 1(3):369-380

Kenyon NH, Amir A, Cramp A (1995) Geometry of the younger sediment bodies of the Indus Fan. In: Pickering KT, Hiscott RN, Kenyon NH, Lucchi FR, Smith RDA (eds) Atlas of deep-water environments: architectural style in turbidite systems. Chapman and Hall, London, pp 89-93
Kodagali VN, Jauhari P (1999) The meandering Indus channels: study in a small area by the multibeam swath bathymetry system-Hydrosweep. Curr Sci $76(2): 240-243$

Kolla V, Coumes F (1984) Morpho-acoustic and sedimentologic characteristics of the Indus Fan. Geo-Mar Lett 3:133-139

Kolla V, Coumes F (1987) Morphology, internal structure, seismic stratigraphy and sedimentation of Indus Fan. Bull Am Assoc Petrol Geol 71:650-677

Kolla V, Coumes F (1990) Extension of structural and tectonic trends from the Indian subcontinent into the eastern Arabian sea. Mar Pet Geol 7:188-196

Kolla V, Coumes F (1991) Seismic stratigraphy, canyon and channel characteristics of the Indus continental margin and upper fan. In: Weimer P, Link MH (eds) Seismic facies and sedimentary processes of submarine fans and turbidite systems. Springer, Berlin, p 438

Lonsdale P, Normark WR, Newman WA (1972) Sedimentation and erosion on Horizon Guyot. Geol Soc Am Bull 83:289-316

Mackenzie D (1997) Ocean floor is laid bare by new satellite data. Science 277:1921

MacKenzie DP, Sclater JG (1971) Evolution of Indian Ocean since late cretaceous. Geophys J R Astro Soc 25:437-528

Mahar GA, Zaigham NA (2013) Identification of temporal shifting trends of submarine Indus Canyon, Pakistan. J Water Resour Prot 5:520-528

Maier KL, Fildani A, McHargue TR, Paull CK, Graham SA, Caress DW (2012) Punctuated deep-water channel migration: high-resolution subsurface data from the Lucia Chica channel system, Offshore California, USA. J Sed Res 82(1):1-8. doi:10.2110/jsr.2012.10

McCall GJH (1997) The geotectonic history of the Makran and adjacent areas of southern Iran. J Asian Earth Sci 15(1997):517-531

McHargue TR, Webb JE (1986) Internal geometry, seismic facies and petroleum potential of canyon and inner fan channels of the Indus submarine fan. Bull Am Asso Petrol Geol 70:161-180

Milliman JD, Quraishee GS, Beg MAA (1984) Sediment discharge from the Indus River to the ocean: past, present and future. In: Haq BU, Milliman JD (eds) Marine geology and oceanography of Arabian Sea and Coastal Pakistan. Van Nostrand Reinhold, New York, pp 66-70

Minshull TA, Lane Cl, Collier JS, Whitmarsh RB (2008) Rifting and magmatism in the Northeastern Arabian Sea. Nat Geosci 1:463-467

Mirza MMQ (2005) Hydrologic modelling approaches for climate impact assessment in South Asia. In: Mirza MMQ, Ahmad QK (eds) Climate change and water resources in South Asia. Taylor and Francis, London, pp 23-54

Mishra R, Pandey DK, Prerna R, Shipboard Scientific Party SK-306 (2015) Active channel systems in the middle Indus Fan: results from high-resolution bathymetry surveys. Curr Sci 108(3):409-412

Naini BR, Kolla V (1982) Acoustic character and thickness of sediments of the Indus Fan and the continental margin of western India. Mar Geol 47:181-195

Naini BR, Talwani M (1982) Structural framework and the evolutionary history of the continental margin of western India. In: Walkins JS, Drake CL (eds) Studies in continental margin geology. Am Asso Petrol Geol Memoir, vol 34, pp 167-191

Najman Y, Appel E, Boudagher-Fadel M, Bown P, Carter A, Garzanti E, Godin L, Han J, Liebke U, Olive G, Parrish R, Vezzoli G (2010) Timing of India-Asia collision: geological, biostratigraphic, and palaeomagnetic constraints. J Geophys Res Solid Earth 115(B12):B12416. doi:10.1029/2010JB007673

NormarkWR (1970) Growth patterns of deep sea fans. Am Asso Petrol Geol Bull 54:2170-2195

Normark WR (1978) Fan valleys, channel and depositional lobes on modern submarine fans: characters for recognition of sandy turbidite environments. Am Asso Petrol Geol Bull 62:912-931

Normark WR (1985) Local morphologic controls and effects of basin geometry on flow processes in deep marine basins. In: Zuffa GG (ed) Provenance of arenites. Reidel, Dordrecht, pp 47-63

Pandey A, Pandey DK (2016) Mechanism of crustal extension in the Laxmi Basin, Arabian Sea. Geodesy Geodyn 6:409-422

Pandey DK, Clift PD, Kulhanek DK, Expedition 355 Scientist (2015) Expedition 355 preliminary report: Arabian Sea Monsoon. International Ocean Discovery Program. doi:10.2204/iodp.pr.355.2015

Parsons B, Sclater JG (1977) An analysis of the variation of ocean floor bathymetry and heat flow with age. J Geophys Res 82:803-827

Peakall J, Kane IA, Masson DG, Keevil G, McCaffrey W, Corney R (2012) Global (latitudinal) variation in submarine channel sinuosity. Geology 40:11-14 
Pratson LF, Ryan WBF (1996) Automated drainage extraction in mapping the Monterey submarine drainage system, California margin. Mar Geophys Res 18:757-777

Prerna R, Pandey DK, Ravi Mishra (2015) Approximation of Flow Patterns for Submarine Channel Systems in the Arabian Sea using a GIS Approach. Int J Adv Remote Sens GIS 4(1):1142-1160

Prins MA, Postma G, Cleveringa J, Cramp A, Kenyon NH (2000) Controls on terrigenous sediment supply to the Arabian Sea during the late Quaternary: the Indus Fan. Mar Geol 169:327-349. doi:10.1016/ S0025-3227(00)00086-4

Ramsey LA, Hovius N, Lague D, Liu C-S (2006) Topographic characteristics of the submarine Taiwan orogen. J Geophys Res Earth Surf 111(F02009):2156-2202. doi:10.1029/2005JF000314

Rao VPC, Lamboy M, Natarajan R (1992) Possible microbial origin of phosphorites on Error Seamount, northwestern Arabian Sea. Mar Geol 106:149-164

Rodriguez M, Fournier M, Chamot-Rooke N, Huchon P, Bourget J, Sorbier M Zaragosi S, Rabaute A (2011) Neotectonics of the Owen fracture zone (NW Indian Ocean): structural evolution of an oceanic strike-slip plate boundary. Geochem Geophy Geosyst 12(12):1-24

Ryan WBF, Carbotte SM, Coplan JO, O'Hara S, Melkonian A, Arko R, Weissel RA, Ferrini V, Goodwillie A, Nitsche F, Bonczkowski J, Zemsky R (2009) Global multi-resolution topography synthesis. Geochem Geophy Geosyst 10:Q03014. doi:10.1029/2008GC002332

Sahni A, Kumar V (1974) Palaeogene palaeobiogeography of the Indian subcontinent. Palaeogeo, Palaeoclim Palaeoecol 15(3):209-226
Shepard FP, Dill RF (1966) Submarine Canyons and other sea valleys. Rand McNally \& Co., Chicago, p 381

Smith WHF, Sandwell DT (1997) Global seafloor topography from satellite altimetry and ship depth soundings. Science 277:1956-1962

Subrahmanyam C, Chand S (2006) Evolution of the passive continental margin of India- a geophysical appraisal. Gondwana Res 10:167-178

Subrahmanyam V, Krishna KS, Ramana MV, Murthy KSR (2008) Marine geophysical investigation across the submarine canyon (Swatch-of-NoGround), northern Bay of Bengal. Curr Sci 94(4):507-513

Talwani M, Reif C (1998) Laxmi ridge-a continental sliver in the Arabian sea. Mar Geophy Res 20:259-271

Vachtman D, Mitchell NC, Gawthorpe R (2013) Morphologic signatures in submarine canyons and gullies, central USA Atlantic continental margins. Mar Petrol Geol 41:250-263. doi:10.1016/j.marpetgeo.2012.02.005

Von Rad U, Tahir M (1997) Late Quaternary sedimentation on the outer Indus shelf and slope (Pakistan): evidence from high resolution seismic data and coring. Mar Geol 138:193-236

Vora KH, Naik DK, Ganesan P, Moraes CN (1991) Offshore extension of Gomati river, Dwarka. Mar Archaeol 2:32-38

Wells JT, Coleman JM (1984) Deltaic morphology and sedimentology with special reference to the Indus River delta. In: Haq BU, Milliman JD (eds) Mar Geol and Oceanography of Arabian Sea and Coastal Pakistan. Van Nostrand Reinhold, New York, pp 85-1000

Wynn RB, Cronin BT, Peakall J (2007) Sinuous deep-water channels: genesis, geometry and architecture. Mar Petrol Geol 24:341-387

\section{Submit your manuscript to a SpringerOpen ${ }^{\odot}$ journal and benefit from:}

- Convenient online submission

- Rigorous peer review

- Immediate publication on acceptance

- Open access: articles freely available online

- High visibility within the field

- Retaining the copyright to your article

Submit your next manuscript at springeropen.com 